OPEN ACCESS

Edited by:

Andrei I. Tarasov,

Ulster University, United Kingdom

Reviewed by:

Tim Heden,

University of Minnesota Health Twin

Cities, United States

Neil G. Docherty,

University College Dublin, Ireland

${ }^{*}$ Correspondence:

Tohru Hira

hira@chem.agr.hokudai.ac.jp

Specialty section: This article was submitted to

Gut Endocrinology,

a section of the journal

Frontiers in Endocrinology

Received: 01 April 2021

Accepted: 17 May 2021

Published: 02 June 2021

Citation:

Hira T, Sekishita M and Hara H (2021) Blood Sampling From Rat Ileal Mesenteric Vein Revealed a Major Role of Dietary Protein in Meal-Induced GLP-1 Response.

Front. Endocrinol. 12:689685. doi: 10.3389/fendo.2021.689685

\section{Blood Sampling From Rat lleal Mesenteric Vein Revealed a Major Role of Dietary Protein in Meal- Induced GLP-1 Response}

\author{
Tohru Hira ${ }^{1,2 *}$, Madoka Sekishita ${ }^{2}$ and Hiroshi Hara ${ }^{3}$ \\ ${ }^{1}$ Research Faculty of Agriculture, Hokkaido University, Sapporo, Japan, ${ }^{2}$ Graduate School of Agriculture, Hokkaido \\ University, Sapporo, Japan, ${ }^{3}$ Faculty of Human Life Science, Fuji Women's University, Ishikari, Japan
}

The present study was conducted to examine region-dependent glucagon-like peptide-1 (GLP-1) responses to "meal ingestion" under physiological (conscious and unrestrained) conditions using rats with a catheter inserted into either the portal vein (PV) or the ileal mesenteric vein (ILMV). After recovery from the cannulation surgery, blood samples were collected from either PV or ILMV catheter before and after the voluntary ingestion of test diets. After an AIN-93G standard diet ingestion, GLP-1 concentration was higher in ILMV than in PV, and postprandial responses of peptide-YY (PYY) had similar trend, while that of glucose dependent-insulinotropic polypeptide showed an opposite trend to GLP-1/PYY responses. In a separated experiment, a protein-enriched diet containing casein at 25\% wt/wt transiently increased GLP-1 concentration only in ILMV; however, a protein-free diet did not increase GLP-1 concentrations in PV or ILMV. These results indicate that postprandial GLP-1 is immediately released from the distal intestine under physiological conditions, and that dietary protein has a critical role in the enhancement of postprandial GLP-1 response.

Keywords: postprandial GLP-1 response, dietary protein, ileal mesenteric vein, portal vein, gut hormone

\section{INTRODUCTION}

Gut hormones are considered to be locally produced in specific regions of the gastrointestinal tract $(1,2)$. Thereby, it has been also considered that secretin, cholecystokinin (CCK), and glucose dependentinsulinotropic polypeptide (GIP) are immediately released from the proximal small intestine, while glucagon like-peptide-1 (GLP-1), glucagon like-peptide-2 (GLP-2), and peptide-YY (PYY) are released from the distal intestine later, in response to meal ingestion. However, GLP-1 and PYY production in the proximal small intestine (3-5) could contribute to a rapid response of these hormones $(6,7)$ after a meal. There is no study to prove this hypothesis under conscious conditions in an animal model.

The primary purpose of the present study was to demonstrate regional gut hormone responses to voluntary meal ingestion under physiological (conscious and unrestrained) conditions, in a rat model. For this purpose, we developed surgical model rats by inserting a catheter into the mesenteric vein of the distal small intestine (ileal mesenteric vein, ILMV). We firstly compared gut hormone concentrations in the plasma samples collected from the ILMV to those from the portal vein $(\mathrm{PV})$ of another group of rats with a portal catheter $(8,9)$. 
In our previous studies using rats, oral administration of dietary peptides (2 $\mathrm{g} / \mathrm{kg}$ dose) significantly increased plasma GLP-1 concentrations $(10,11)$, while the same dose of glucose did not $(10,12)$. These observations raised a hypothesis that proteins in the meal have a critical role in postprandial GLP-1 secretion. To test this hypothesis, we further examined the role of dietary protein in postprandial GLP-1 responses using the PV- or ILMV-cannulated rats, under a voluntary feeding condition.

\section{MATERIALS AND METHODS}

\section{Animals and Diets}

Male Sprague-Dawley rats (7 weeks old) were purchased from Japan SLC (Hamamatsu, Japan). All the animals were housed in individual cages and had free access to water and a semi-purified AIN-93G diet (13). All animal experiments were performed after an acclimation period (3-7 days) in a temperature-controlled room maintained at $23^{\circ} \mathrm{C} \pm 2{ }^{\circ} \mathrm{C}$ with a 12 -h light/dark cycle (08:00-20:00 h, light period). This study has been approved by the Hokkaido University Animal Committee, and animals were maintained in accordance with the Guide for the Care and Use of Laboratory Animals of Hokkaido University.

\section{Surgical Preparation}

Rats were anesthetized with sodium pentobarbital $(50 \mathrm{mg} / \mathrm{kg}$ body weight; Somnopentyl Injection, Kyoritsu Seiyaku Co., Tokyo, Japan), and then the laparotomy was performed.
The small tip (6-7 $\mathrm{mm}$ ) of a polyethylene catheter (SP 28; ID $0.4 \mathrm{~mm}$, OD $0.8 \mathrm{~mm}$ for PV, SP 10; ID $0.28 \mathrm{~mm}$, OD $0.61 \mathrm{~mm}$ for ILMV, Natsume Seisakusyo, Tokyo, Japan) was connected to a silicone catheter (Silascon no. 00, ID $0.5 \mathrm{~mm}$, OD $1.0 \mathrm{~mm}$; Dow Corning Co.) approximately $30 \mathrm{~cm}$ long. The polyethylene catheter was directly inserted into the PV and/or ILMV at the position where 2-3 of ileal veins join (Figure 1), and then fixed with an instant adhesive. The catheter was prefilled with sterile saline that contained heparin (50 IU/ml; Ajinomoto, Tokyo, Japan). The free end of the catheter was dorsally exteriorized and fixed behind the neck, and the abdomen was then closed with surgical threads. The abdominal skin incision was closed with Michel clips. We flushed the catheter with heparinized saline daily to maintain patency. After a recovery period of 3-4 days, rats without catheter-clogging were used for following experiments. Using these model rats, we conducted the experiments under non-anesthetized and unrestrained conditions (8). After the experiments, rats were euthanized by exsanguination under anesthesia with sodium pentobarbital (50 mg/kg body weight).

\section{Meal Tolerance Tests (MTTs)}

During the acclimation period, rats were trained to consume a certain amount of diet $(10 \mathrm{~g} / \mathrm{kg})$ within $60 \mathrm{~min}$, after overnight fasting. After the recovery period, rats were fasted for $24 \mathrm{~h}$, and the basal $(0 \mathrm{~min})$ blood sample $(200 \mu \mathrm{L})$, was collected from the catheter. The rats were then provided the test diet $(10 \mathrm{~g} / \mathrm{kg}$, Table 1) for $60 \mathrm{~min}$. Blood samples $(200 \mu \mathrm{L}$ each $)$ were collected

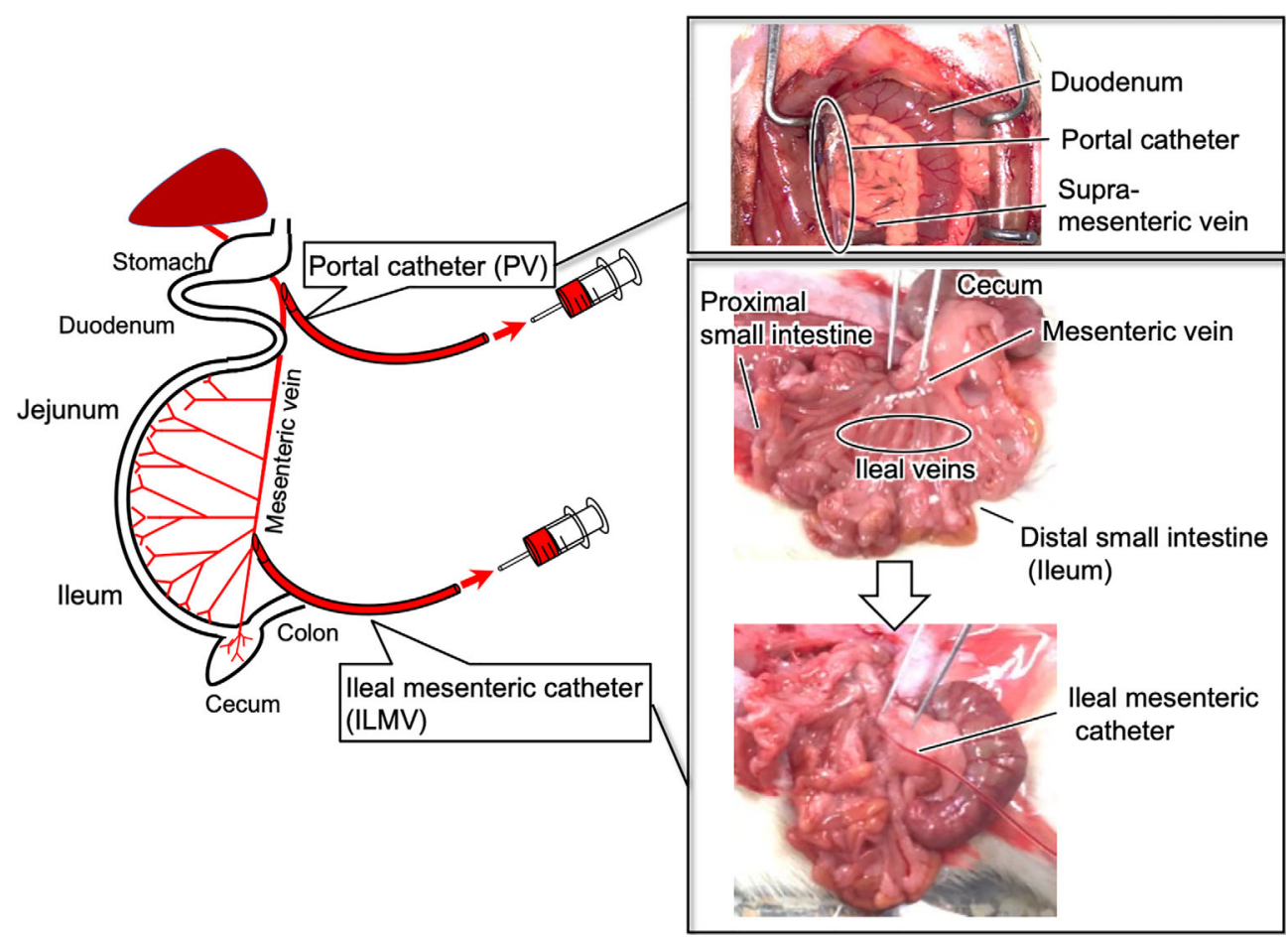

FIGURE 1 | Summary of cannulation into the ileal mesenteric vein and the portal vein in rats. 
TABLE 1 | Compositions of diets.

\begin{tabular}{|c|c|c|c|}
\hline \multirow[t]{3}{*}{ Ingredient } & \multirow{3}{*}{$\frac{\text { Experiment } 1}{\text { AIN-93G }}$} & \multicolumn{2}{|c|}{ Experiment 2} \\
\hline & & Control & Protein-fre \\
\hline & & \multicolumn{2}{|c|}{$\mathbf{g} / \mathbf{k g}$ of diet } \\
\hline Casein $^{1}$ & 200 & 250 & 0 \\
\hline Cornstarch & 397.486 & 350.486 & 600.486 \\
\hline Dextrinized cornstarch ${ }^{2}$ & 132 & 132 & 132 \\
\hline Sucrose & 85 & 70 & 70 \\
\hline Soybean oil & 70 & 70 & 70 \\
\hline Cellulose $^{3}$ & 65 & 50 & 50 \\
\hline Mineral mixture ${ }^{4}$ & 35 & 35 & 35 \\
\hline Vitamin mixture ${ }^{4}$ & 10 & 10 & 10 \\
\hline L-Cystine & 3 & 0 & 0 \\
\hline Choline bitartrate & 2.5 & 2.5 & 2.5 \\
\hline tert-Butylhydroquinone & 0.014 & 0.014 & 0.014 \\
\hline Energy density (kcal/g) & 3.9 & 3.9 & 3.9 \\
\hline
\end{tabular}

at $15,30,60,90$, and 120 min after providing the diet. MTTs were started around 10:00 AM and conducted during the light period. All blood samples were mixed with ethylenediamine tetraaceticacid (EDTA) solution $(1.8 \mathrm{mg} / \mathrm{mL}$ blood), Pefabloc SC (AEBSF; 4-(2-aminoethyl)benzenesulfonyl fluoride; Roche, $1 \mathrm{mg} / \mathrm{mL}$ blood), Protease inhibitor Cocktail (P2714; SIGMA, $1 \mu \mathrm{L} / \mathrm{mL}$ blood), and DPP-IV inhibitor (DPP4-010; Millipore, $10 \mu \mathrm{L} / \mathrm{mL}$ blood), in a syringe. Plasma was separated and frozen at $-80^{\circ} \mathrm{C}$ until measurement of glucose and gut hormone concentrations. Plasma glucose concentrations were measured using the Glucose CII test kit (Wako). Active GLP-1, total GIP, total PYY, and insulin concentrations were measured using the MILLIPLEX MAP Rat Metabolic Hormone Magnetic Bead Panel (Millipore, Billerica, MA). Intra-assay precision is $1-8 \%$; interassay precision is 7-29\%; standard curve ranges for GLP-1 (Active) is $41-30,000 \mathrm{pg} / \mathrm{mL}$, for GIP (Total) is $2.7-2,000 \mathrm{pg} /$ $\mathrm{mL}$, for PYY (Total) is $7-5,000 \mathrm{pg} / \mathrm{mL}$, respectively. Total GLP-1 levels were measured using the ELISA kits (EZGLP1T-36K, Millipore). Intra-assay precision is $<5 \%$; inter-assay precision is $<12 \%$; standard curve range is $4.1-1000 \mathrm{pM}$.

Experiment 1 was conducted to compare gut hormone and glycemic responses after ingestion of a standard meal. Rats with the PV or ILMV catheter were fed the standard diet (AIN-93G) containing casein at $20 \%$ as a protein source (Table 1).

Experiment 2 was conducted to compare gut hormone and glycemic responses to the diet with or without protein source (Table 1). The control diet contained casein $(25 \% \mathrm{wt} / \mathrm{wt})$ as a protein-enriched diet, in order to emphasize the impact of dietary proteins. The protein-free diet was devoid of casein, and the amount of casein $(250 \mathrm{~g} / \mathrm{kg}$ diet $)$ was replaced by corn starch.

\section{Statistical Analysis}

Results are expressed as mean \pm SEM. Area under the curve (AUC) of plasma parameter concentrations during the MTT was calculated by the trapezoidal rule. Statistical significance was determined using two-way repeated-measures ANOVA to assess the main effects (time, region of blood sampling, or diet), as well as their interaction effects, using JMP Pro software version 12 (SAS Institute, NC, USA). Statistical significance $(\mathrm{P}<0.05)$ between mean values was evaluated using Student's t-test or Dunnett's test as described in figure legends.

\section{RESULTS}

In experiment 1 , rats consumed more than $95 \%$ of the diet $(2.80 \pm$ $0.05 \mathrm{~g}$ in the PV group and $2.75 \pm 0.04 \mathrm{~g}$ in the ILMV group) provided at the dose of $10 \mathrm{~g} / \mathrm{kg}$, within $15 \mathrm{~min}$. As both groups consumed almost equivalent amount of the diet, the following results could not be attributed to a difference in the amount of food intake.

Plasma glucose concentrations (Figure 2A) elevated immediately in both groups, glucose concentrations at 15,60 , and 120 min were significantly higher in the PV group than those in the ILMV group, accordingly, the PM group had higher AUC of glucose than the ILMV group (Figure 2B). The concentration of active GLP-1 increased in the ILMV group immediately (15 min) after ingesting the meal, whereas it showed no increment in the PV group (Figure 2C). The AUC of GLP-1 was higher in the ILMV group than in the $\mathrm{PV}$ group (Figure 2D). GIP concentrations continuously increased over time in both groups, but the increment and the AUC were higher in the PV than in the ILMV group (Figures 2E, F). The concentration of PYY transiently increased only in the ILMV group, and a significant difference between the regions was detected by two-way ANOVA (Figure 2G). The AUC of PYY was not significantly different between two groups (Figure $\mathbf{2 H}$ ). Insulin concentrations were similarly elevated both in the PV and the ILMV, and not significantly different between the regions (Supplementary Figures 1A, B).

In experiment 2, rats with the PV catheter consumed more than $95 \%$ of test diets $(2.63 \pm 0.05 \mathrm{~g}$ in the control group, $2.51 \pm$ $0.05 \mathrm{~g}$ in the protein-free group) provided at a dose of $10 \mathrm{~g} / \mathrm{kg}$, within $15 \mathrm{~min}$. Rats with the ILMV catheter consumed more than $92 \%$ of test diets $(2.48 \pm 0.05 \mathrm{~g}$ in control group, $2.38 \pm$ $0.11 \mathrm{~g}$ in the protein-free group) within $15 \mathrm{~min}$, and more than $97 \%$ of the respective diets within $60 \mathrm{~min}$.

Basal (0 min) glucose concentrations $(\mathrm{mg} / \mathrm{dL})$ were similar in all the groups; $86.5 \pm 2.5,84.5 \pm 4.0,83.3 \pm 4.4$, and $90.9 \pm 4.8$ in Control/PV, Protein-free/PV (Pro-free/PV), Control/ILMV, and Protein-free/ILMV (Pro-free/ILMV), respectively. Glycemic response to both of test diets were higher in the $\mathrm{PV}$ group than in the ILMV group (Figures 3A, B).

Because basal values of gut hormone concentrations had unexpectedly high variances, results are presented as changes from the basal values (Figure 3). Active GLP-1 concentrations $(\mathrm{pM})$ were $28.4 \pm 7.1,60.3 \pm 17.3,239.0 \pm 146.1$, and $292.1 \pm$ 150.5; total GLP-1 concentrations $(\mathrm{pM})$ were $25.7 \pm 4.8,54.8 \pm$ $11.4,46.8 \pm 17.5$, and 75.2 \pm 27.0 ; total GIP concentrations (pM) were $9.6 \pm 1.3,8.8 \pm 0.8,13.9 \pm 1.6$, and $15.4 \pm 2.5$; PYY concentrations $(\mathrm{pM})$ were $28.0 \pm 6.0,44.3 \pm 6.6,94.8 \pm 55.8$, 


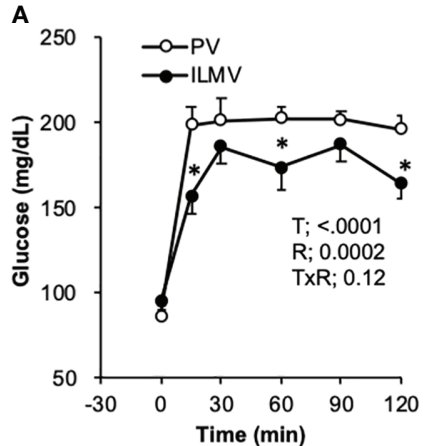

B

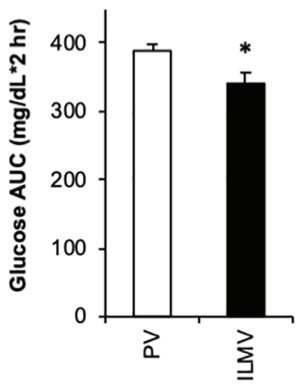

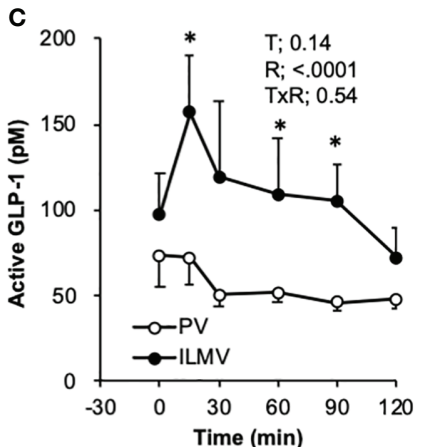

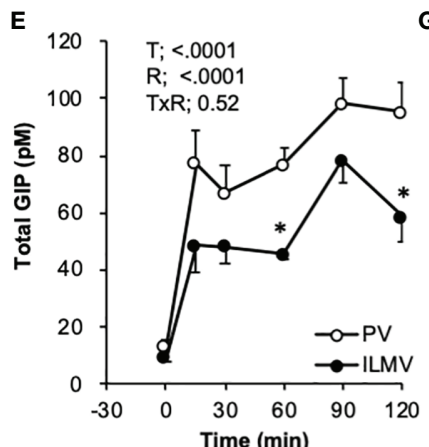

D

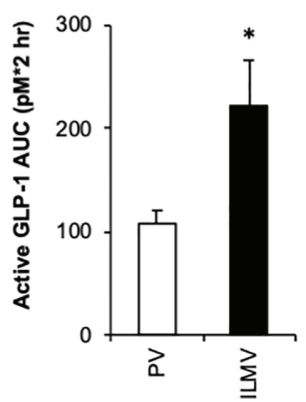

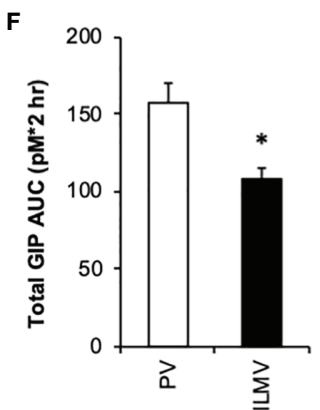

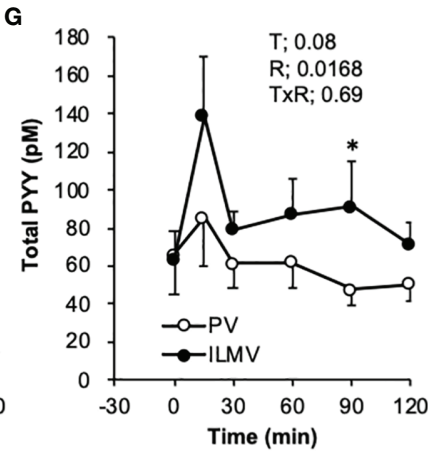

H

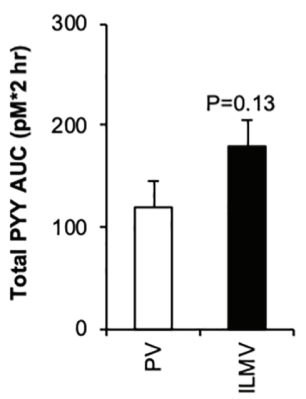

FIGURE 2 | Changes in glucose and gut hormone concentrations in the portal vein (PV) plasma and in the ileal mesenteric vein (ILMV) plasma after ingestion of the standard diet. Rats were provided the AIN-93G diet at the dose of $10 \mathrm{~g} / \mathrm{kg}$ body weight, after 24-h fasting. Blood samples were collected from the catheter before ( 0 min) and after providing the meal. Data are presented as mean values and SEM ( $n=10$ in PV, and $n=6$ in ILMV). P values calculated by two-way repeatedmeasures ANOVA for effects of time $(T)$, the region of blood sampling (R), and their interactions (TxR) are presented in each of the panels. Asterisks $\left(^{\star}\right)$ indicate significant difference between the value at the same time point $(\mathbf{A}, \mathbf{C}, \mathbf{E}, \mathbf{G})$ or between the AUC $(\mathbf{B}, \mathbf{D}, \mathbf{F}, \mathbf{H})(\mathbf{P}<0.05, S t u d e n t$ 's t-test).

and $106.1 \pm 44.2$, in the Control/PV, Pro-free/PV, Control/ ILMV, and Pro-free/ILMV groups, respectively.

In the PV, plasma glucose was higher in the Pro-free group than the control group (Figure 3A). No significant differences were observed between two groups in the ILMV (Figure 3B). Active GLP-1 concentration was transiently (15 min) elevated only in the Control/ILMV group with a significant difference as compared to the value at the same time point in the Pro-free/ILMV group (Figures 3C, D). We additionally measured the total GLP-1 concentration, as it reflects GLP-1 release rather than biologically active GLP-1. Because plasma samples in two rats (one in the Control/PV group and another in the Pro-free/ILMV group) did not remain sufficient for total GLP-1 measurement, the data were obtained respectively from 4 and 5 rats in these groups. Only in the ILMV group, total GLP-1 concentration sharply increased $(\mathrm{P}<0.05$ vs 0 min within the group, and, vs Pro-free group at the same time point) 15 min after ingestion of the control diet (Figures 3E, F). The Protein-free diet failed to increase total GLP-1 concentrations in the ILMV group. Total GIP concentrations increased similarly by both of diets in the PV and ILMV, respectively (Figures 3G, H). The Protein-free diet failed to increase total GLP-1 concentrations in the ILMV group. Postprandial responses of PYY (Figures 3I, J) were overall similar to those of GLP-1 both in the PV and ILMV groups. Incremental AUC (Supplemental Figure 2) of glucose was higher in PV of the Pro-free group than in PV of the control group, and incremental AUC of total GLP-1was higher in ILMV of the control group than the Pro-free group.

\section{DISCUSSION}

It has been widely accepted that postprandial glucose absorption occurs in the proximal small intestine based on old and valuable studies (14-16). In the present study, differences in glycemia between the PV and ILMV groups probably reflects avid glucose absorption in the proximal small intestine. This is also supported by the result in experiment 2 , in which the glycemic response was higher to the Pro-free diet than to the control diet in the PV group, but the difference was not observed in the ILMV group. To the best of our knowledge, this is possibly the first study demonstrating postprandial glycemia in veins of different regions of the intestine under physiological (conscious, unrestrained, and voluntary feeding) conditions.

Although we had expected similar profiles of GLP-1 responses, possibly at different degrees between the PV and ILMV groups, GLP-1 responses to the normal diet apparently differed. These results strongly suggest that GLP-1 is initially released from the ileum in response to meal ingestion. Such an interpretation agrees with the abundant distribution of GLP-1 producing cells in the distal than in the proximal small intestine (3-5). The immediate response (at $15 \mathrm{~min}$ ) appears discrepant when considering the transit of luminal nutrients after meal ingestion. This could be explained by a "proximal-distal enteroendocrine loop" (17-19), in which certain proximal signals and the vagus nerve mediate GLP-1 release from the distal intestine. However, it is still possible that some of nutritional components immediately reached the middle- 


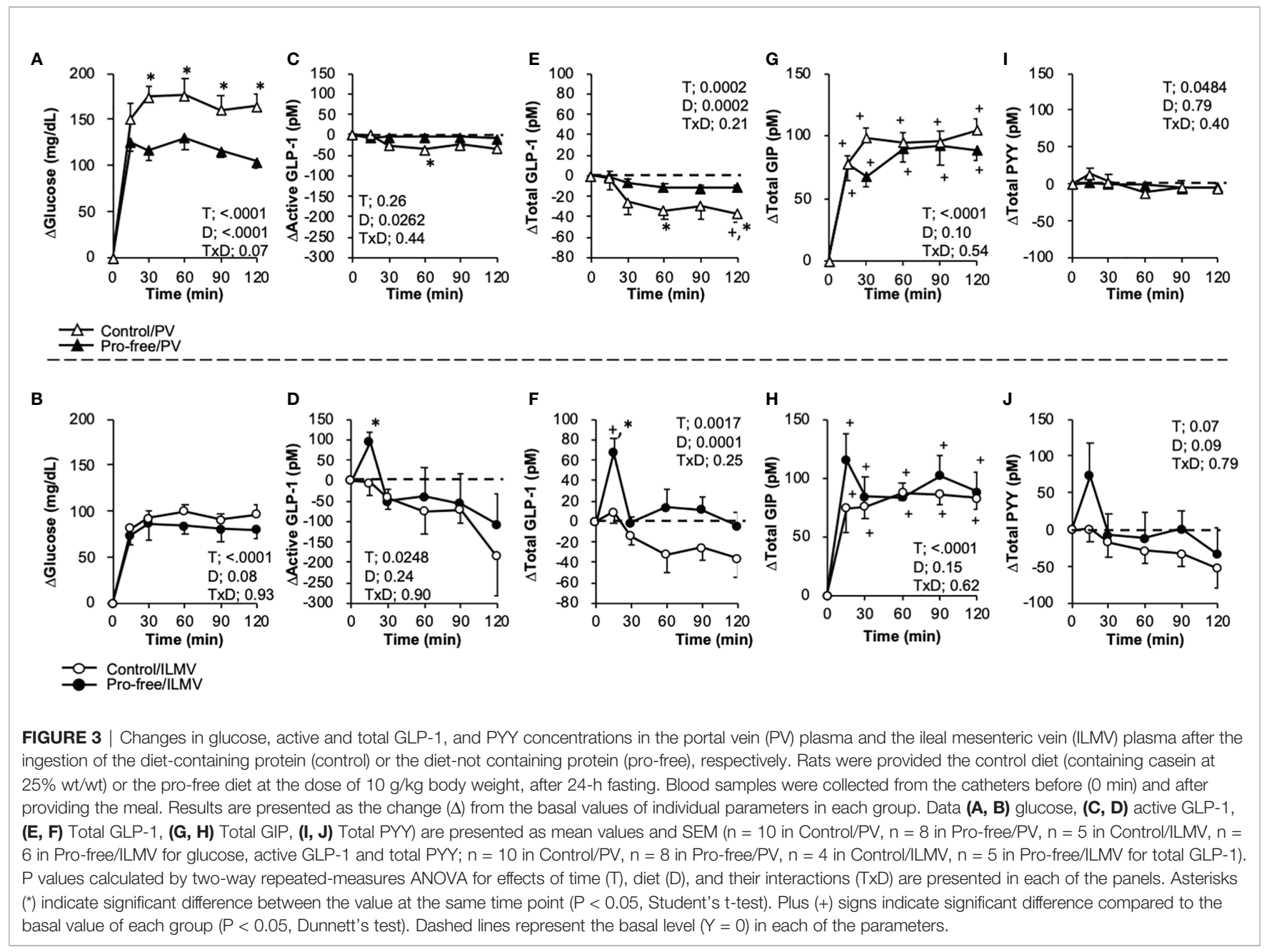

distal part of small intestine so that they directly stimulated L cells locally.

In contrast to GLP-1, postprandial GIP concentrations were higher in the PV than in the ILMV, which could be explained by the localization of GIP-producing $\mathrm{K}$ cells in the proximal small intestine (3-5). Such region-dependent responses in glucose, GLP-1, and GIP levels help to validate that our cannulation models (especially ILMV) are useful for distinguishing the events that occur in the proximal and distal intestine.

The protein-free diet failed to increase GLP-1 concentrations both in the PV and ILMV, indicating that protein is an essential component for the induction of GLP-1 release in response to the "meal". This is partially supported by previous studies demonstrating that dietary proteins had a potent effect on GLP-1 secretion (20-23) as compared to that of carbohydrate and fat. As expected, profiles of PYY response were largely similar to that of GLP-1 responses in both experiments. This is consistent with the fact that these hormones are co-produced in L cells of the distal intestine, and with previous studies demonstrating the potent effect of dietary proteins on PYY secretion $(21,23,24)$.

GLP-1 and PYY-producing cells exist abundantly in the ileum and colon, nevertheless these responses appeared within $15 \mathrm{~min}$ postprandially. Such quick responses might be mediated by neurohumoral reflexes triggered by sensing nutrients in the proximal small intestine $(17-19,25,26)$.

Dietary fat is known to stimulate PYY in animal models and humans (2). Although all of test diet contained soybean oil at 7\% (wt/wt), PYY concentrations did not increase in the ILMV after Pro-free diet ingestion (Figure 3H). In previous rat (approx. $300 \mathrm{~g}$ body weight) experiments, ileal infusion of $100 \mathrm{mM}(28.2$ $\mathrm{mg} / \mathrm{mL}, 200 \mu \mathrm{L} / \mathrm{min}$ ) oleic acid for $30 \mathrm{~min}$ (totally $169 \mathrm{mg}$ oleic acid) induced much smaller PYY response than that of $5 \%$ peptone (totally $300 \mathrm{mg}$ peptone) (27), and duodenal administration of $3 \mathrm{ml}$ of $150 \mathrm{mM}(42.3 \mathrm{mg} / \mathrm{mL})$ oleic acid (totally $127 \mathrm{mg}$ oleic acid $=1.14 \mathrm{kcal}$ ) induced much smaller PYY response than that of a liquid meal (totally $21 \mathrm{~kJ}=5 \mathrm{kcal}$ ) (28). In the present study, rats ingested approximately $200 \mathrm{mg}(70 \mathrm{mg}$ fat/g diet x 2.5-2.8 g diet) of fat in MTTs. Because fat content was apparently lower than carbohydrate and protein contents in the diets, and these nutrients need to be emptied from the stomach into the small intestine to exert stimulatory effect on GIP/GLP-1/ PYY secretions, we speculate that the amount of fat presented in the small intestine was not sufficient to trigger PYY secretion.

Insulin is not secreted from the intestine, and its secretion is stimulated by multiple factors such as GLP-1, GIP, glucose, amino acids, and fatty acid in the plasma, therefore, we are not 
able to provide relevant reasons for similar insulin responses observed in the present study regardless of the regions of blood sampling and of the diets given (Supplementary Figure 1).

Concentrations of plasma gut hormones could be affected by the rate of blood flow and by merging with the blood outside from the intestine such as the pancreas and kidney (29). Portal blood flow is increased by meal ingestion and plasma glucose (30-33). Decrements in GLP-1 concentrations observed in PV of rats fed the protein free diet may be due to dilution by these physiological factors. Blood sampling from a mesenteric vein tributary from the proximal small intestine would be desirable to exclude these effects, though it is technically challenging for repeated blood sampling in awake rats.

Liberated peptides $(10,11,34-36)$ and/or amino acids $(37,38)$ from the dietary proteins likely stimulated GLP-1 release. We speculate that dipeptidyl peptidase-IV (DPP-IV) inhibitory peptides liberated from the dietary proteins $(10,34,39-43)$ are absorbed in the small intestine, wherein they protect GLP-1 from degradation by DPP-IV in the plasma. Measurements of active GLP-1, total GLP-1 concentrations, their ratio, and DPP-IV activity in systemic bloods collected without full protease protection will be needed to examine the hypothesis in future studies. A previous study demonstrated greater effect of carbohydrates than proteins on GLP-1 release in conscious rats (44) using lymph fistula and duodenal nutrient infusion. The opposite conclusion to our study would be attributed to the differential experimental conditions.

It seemed surprising that the protein-free diet did not increase GLP-1 concentrations even though the diet mainly (more than $80 \% \mathrm{wt} / \mathrm{wt}$ ) consisted of digestible carbohydrates. This could be because carbohydrates were rapidly digested and absorbed as monosaccharides in the proximal small intestine, as suggested by the data obtained for glycemic and GIP responses (experiment 1). The dose of the test diet at $10 \mathrm{~g} / \mathrm{kg}$ was possibly insufficient to detect an elevation of GLP-1 concentrations for the protein-free (high carbohydrate) diet, even in the mesenteric and the portal veins. Indeed, we could not detect any increment in GLP-1 levels by oral administration of glucose or dextrin at the dose of 2-3 g/ $\mathrm{kg}(45,46)$, whereas oral administration of protein hydrolysates at $2 \mathrm{~g} / \mathrm{kg}$ sufficiently enhanced GLP-1 concentrations in the peripheral vein of normal rats $(10,11)$.

It is unclear why the values of active GLP-1 concentration were higher than that of total GLP-1 concentration in the present study. The discrepancy might come from the difference in methodology (a multiplex assay system and a conventional ELISA kit). However, the postprandial responses were almost parallel between both forms of GLP-1s. Therefore, our results seem to appropriately represent GLP-1 secretory response at the postprandial state. Another limitation in the present study is that

\section{REFERENCES}

1. Gribble FM, Reimann F. Enteroendocrine Cells: Chemosensors in the Intestinal Epithelium. Annu Rev Physiol (2016) 78:277-99. doi: 10.1146/ annurev-physiol-021115-10543

2. Steinert RE, Feinle-Bisset C, Asarian L, Horowitz M, Beglinger C, Geary N. Ghrelin CCK. Glp-1, and PYY(3-36): Secretory Controls and Physiological Roles in Eating and Glycemia in Health, Obesity, and it is not possible to separate circulated blood from the ILMV and PV blood samples. In addition, comparing with postprandial GLP-1 concentrations in systemic blood samples would help to distinguish secreted, circulated, and degraded GLP-1s. If we can successfully cannulate into the cecal vein or mesenteric artery, it will be possible to evaluate the region-specific hormone responses or nutrient/drug absorption.

In summary, using novel ILMV cannulated model rats and comparing them to PV cannulated model rats, it was demonstrated that postprandial GLP-1 is released from the distal intestine under physiological conditions. Furthermore, by comparing postprandial GLP-1 responses to the diets with or without protein, it was revealed that protein in the meal has a critical role in triggering postprandial GLP-1 responses from the distal intestine.

\section{DATA AVAILABILITY STATEMENT}

The raw data supporting the conclusions of this article will be made available by the authors, without undue reservation.

\section{ETHICS STATEMENT}

The animal study was reviewed and approved by The Hokkaido University Animal Committee.

\section{AUTHOR CONTRIBUTIONS}

TH, MS, and $\mathrm{HH}$ designed research. MS, and TH conducted research and analyzed data. TH and MS wrote the paper. TH had primary responsibility for final content. All authors contributed to the article and approved the submitted version.

\section{FUNDING}

This work was supported by JSPS KAKENHI Grant Number 26252016 and $18 \mathrm{~K} 19158$.

\section{SUPPLEMENTARY MATERIAL}

The Supplementary Material for this article can be found online at: https://www.frontiersin.org/articles/10.3389/fendo.2021. 689685/full\#supplementary-material

After Rygb. Physiol Rev (2017) 97(1):411-63. doi: 10.1152/physrev. 00031.2014

3. Egerod KL, Engelstoft MS, Grunddal KV, Nøhr MK, Secher A, Sakata I, et al. A Major Lineage of Enteroendocrine Cells Coexpress CCK, Secretin, GIP, Glp-1, PYY, and Neurotensin But Not Somatostatin. Endocrinology (2012) 153(12):5782-95. doi: 10.1210/en.2012-1595

4. Habib AM, Richards P, Cairns LS, Rogers GJ, Bannon CA, Parker HE, et al. Overlap of Endocrine Hormone Expression in the Mouse Intestine Revealed 
by Transcriptional Profiling and Flow Cytometry. Endocrinology (2012) 153 (7):3054-65. doi: 10.1210/en.2011-2170

5. Svendsen B, Pedersen J, Albrechtsen NJ, Hartmann B, Toräng S, Rehfeld JF, et al. An Analysis of Cosecretion and Coexpression of Gut Hormones From Male Rat Proximal and Distal Small Intestine. Endocrinology (2015) 156 (3):847-57. doi: 10.1210/en.2014-1710

6. O'Connor KL, Scisco JL, Smith TJ, Young AJ, Montain SJ, Price LL, et al. Altered Appetite-Mediating Hormone Concentrations Precede Compensatory Overeating After Severe, Short-Term Energy Deprivation in Healthy Adults. J Nutr (2016) 146(2):209-17. doi: 10.3945/jn.115.217976

7. Parry SA, Smith JR, Corbett TR, Woods RM, Hulston CJ. Short-Term, HighFat Overfeeding Impairs Glycaemic Control But Does Not Alter Gut Hormone Responses to a Mixed Meal Tolerance Test in Healthy, NormalWeight Individuals. Br J Nutr (2017) 117(1):48-55. doi: 10.1017/ S0007114516004475

8. Hara H, Funabiki R, Iwata M, Yamazaki K. Portal Absorption of Small Peptides in Rats Under Unrestrained Conditions. J Nutr (1984) 114(6):11229. doi: $10.1093 / \mathrm{jn} / 114.6 .1122$

9. Braillon A, Brody MJ. A Simple Method for Chronic Cannulation of the Portal Vein in Intact Unrestrained Rats. Am J Physiol (1988) 255(2 Pt 1): G191-3. doi: 10.1152/ajpgi.1988.255.2.G191

10. Ishikawa $\mathrm{Y}$, Hira $\mathrm{T}$, Inoue $\mathrm{D}$, Harada $\mathrm{Y}$, Hashimoto $\mathrm{H}$, Fujii M, et al. Rice Protein Hydrolysates Stimulate GLP-1 Secretion, Reduce GLP-1 Degradation, and Lower the Glycemic Response in Rats. Food Funct (2015) 6(8):2525-34. doi: $10.1039 /$ c4fo01054j

11. Higuchi N, Hira T, Yamada N, Hara H. Oral Administration of Corn Zein Hydrolysate Stimulates GLP-1 and GIP Secretion and Improves Glucose Tolerance in Male Normal Rats and Goto-Kakizaki Rats. Endocrinology (2013) 154(9):3089-98. doi: 10.1210/en.2012-2275

12. Hira T, Koga T, Sasaki K, Hara H. Canagliflozin Potentiates GLP-1 Secretion and Lowers the Peak of GIP Secretion in Rats Fed a High-Fat High-Sucrose Diet. Biochem Biophys Res Commun (2017) 492(2):161-5. doi: 10.1016/ j.bbrc.2017.08.031

13. Reeves PG. Components of the AIN-93 Diets as Improvements in the AIN76A Diet. J Nutr (1997) 127(5 Suppl):838S-41S. doi: 10.1093/jn/127.5.838S

14. Borgstrom B, Dahlqvist A, Lundh G, Sjovall J. Studies of Intestinal Digestion and Absorption in the Human. J Clin Invest (1957) 36(10):1521-36. doi: 10.1172/JCI103549

15. Rider AK, Schedl HP, Nokes G, Shining S. Small Intestinal Glucose Transport. Proximal-distal Kinetic Gradients. J Gen Physiol (1967) 50(5):1173-82. doi: 10.1085/jgp.50.5.1173

16. Fisher RB, Parsons DS. Glucose Absorption From Surviving Rat Small Intestine. J Physiol (1949) 110(3-4):281-93. doi: 10.1113/jphysiol.1949.sp004438

17. Rocca AS, Brubaker PL. Role of the Vagus Nerve in Mediating Proximal Nutrient-Induced Glucagon-Like Peptide-1 Secretion. Endocrinology (1999) 140(4):1687-94. doi: 10.1210/endo.140.4.6643

18. Brubaker PL, Anini Y. Direct and Indirect Mechanisms Regulating Secretion of Glucagon-Like Peptide-1 and Glucagon-Like Peptide-2. Can J Physiol Pharmacol (2003) 81(11):1005-12. doi: 10.1139/y03-107

19. Hira T, Mochida T, Miyashita K, Hara H. GLP-1 Secretion is Enhanced Directly in the Ileum But Indirectly in the Duodenum by a Newly Identified Potent Stimulator, Zein Hydrolysate, in Rats. Am J Physiol Gastrointest Liver Physiol (2009) 297(4):G663-71. doi: 10.1152/ajpgi.90635.2008

20. Raben A, Agerholm-Larsen L, Flint A, Holst JJ, Astrup A. Meals With Similar Energy Densities But Rich in Protein, Fat, Carbohydrate, or Alcohol Have Different Effects on Energy Expenditure and Substrate Metabolism But Not on Appetite and Energy Intake. Am J Clin Nutr (2003) 77(1):91-100. doi: 10.1093/ajcn/77.1.91

21. van der Klaauw AA, Keogh JM, Henning E, Trowse VM, Dhillo WS, Ghatei MA, et al. High Protein Intake Stimulates Postprandial GLP1 and PYY Release. Obes (Silver Spring) (2013) 21(8):1602-7. doi: 10.1002/oby.20154

22. Ripken D, van der Wielen N, Wortelboer HM, Meijerink J, Witkamp RF, Hendriks HF. Nutrient-Induced Glucagon Like Peptide-1 Release is Modulated by Serotonin. J Nutr Biochem (2016) 32:142-50. doi: 10.1016/ j.jnutbio.2016.03.006

23. Dougkas A, Östman E. Protein-Enriched Liquid Preloads Varying in Macronutrient Content Modulate Appetite and Appetite-Regulating Hormones in Healthy Adults. J Nutr (2016) 146(3):637-45. doi: 10.3945/ jn.115.217224
24. Batterham RL, Heffron H, Kapoor S, Chivers JE, Chandarana K, Herzog H, et al. Critical Role for Peptide YY in Protein-Mediated Satiation and BodyWeight Regulation. Cell Metab (2006) 4(3):223-33. doi: 10.1016/ j.cmet.2006.08.001

25. Dumoulin V, Dakka T, Plaisancie P, Chayvialle JA, Cuber JC. Regulation of Glucagon-Like Peptide-1-(7-36) Amide, Peptide YY, and Neurotensin Secretion by Neurotransmitters and Gut Hormones in the Isolated Vascularly Perfused Rat Ileum. Endocrinology (1995) 136(11):5182-8. doi: 10.1210/endo.136.11.7588257

26. Plaisancié P, Bernard C, Chayvialle JA, Cuber JC. Release of Peptide YY by Neurotransmitters and Gut Hormones in the Isolated, Vascularly Perfused Rat Colon. Scand J Gastroenterol (1995) 30(6):568-74. doi: 10.3109/ 00365529509089791

27. Dumoulin V, Moro F, Barcelo A, Dakka T, Cuber JC, et al. Glucagon-Like peptide-1, and Neurotensin Responses to Luminal Factors in the Isolated Vascularly Perfused Rat Ileum. Endocrinology (1998) 139(9):3780-6. doi: 10.1210/endo.139.9.6202

28. Anini Y, Fu-Cheng X, Cuber JC, Kervran A, Chariot J, Roz C. Comparison of the Postprandial Release of Peptide YY and Proglucagon-Derived Peptides in the Rat. Pflugers Arch (1999) 438(3):299-306. doi: 10.1007/s004240050913

29. Lyubimov AV, DeSesso JM, Jacobson CF, Williams AL. "Anatomical and Physiological Parameters That Influence Gastrointestinal Absorption." In Encyclopedia of Drug Metabolism and Interactions, a.V. Lyubimov (2012). doi: 10.1002/9780470921920.edm022

30. Richardson PD, Withrington PG. Liver Blood Flowand Nervous Control of Liver Blood Flow. Gastroenterology (1981) 81(1):159-73. doi: 10.1016/00165085(81)90668-5

31. Rhoden D, Matheson PJ, Carricato ND, Spain DA, Garrison RN. ImmuneEnhancing Enteral Diet Selectively Augments Ileal Blood Flow in the Rat. J Surg Res (2002) 106(1):25-30. doi: 10.1006/jsre.2002.6424

32. Matheson PJ, Wilson MA, Garrison RN. Regulation of Intestinal Blood Flow. J Surg Res (2000) 93(1):182-96. doi: 10.1006/jsre.2000.5862

33. Daemen MJ, Thijssen HH, van Essen H, Vervoort-Peters HT, Prinzen FW, Struyker Boudier HA, et al. Liver Blood Flow Measurement in the Rat. The Electromagnetic Versus the Microsphere and the Clearance Methods. J Pharmacol Methods (1989) 21(4):287-97. doi: 10.1016/0160-5402(89) 90066-1

34. Mochida T, Hira T, Hara H. The Corn Protein, Zein Hydrolysate, Administered Into the Ileum Attenuates Hyperglycemia Via its Dual Action on Glucagon-Like Peptide-1 Secretion and Dipeptidyl peptidase-IV Activity in Rats. Endocrinology (2010) 151(7):3095-104. doi: 10.1210/ en.2009-1510

35. Calbet JA, Holst JJ. Gastric Emptying, Gastric Secretion and Enterogastrone Response After Administration of Milk Proteins or Their Peptide Hydrolysates in Humans. Eur J Nutr (2004) 43(3):127-39. doi: 10.1007/ s00394-004-0448-4

36. Hall WL, Millward DJ, Long SJ, Morgan LM. Casein and Whey Exert Different Effects on Plasma Amino Acid Profiles, Gastrointestinal Hormone Secretion and Appetite. Br J Nutr (2003) 89(2):239-48. doi: 10.1079/BJN2002760

37. Greenfield JR, Farooqi IS, Keogh JM, Henning E, Habib AM, Blackwood A, et al. Oral Glutamine Increases Circulating Glucagon-Like Peptide 1, Glucagon, and Insulin Concentrations in Lean, Obese, and Type 2 Diabetic Subjects. Am J Clin Nutr (2009) 89(1):106-13. doi: 10.3945/ajcn.2008.26362

38. Alamshah A, McGavigan AK, Spreckley E, Kinsey-Jones JS, Amin A, Tough IR, et al. L-Arginine Promotes Gut Hormone Release and Reduces Food Intake in Rodents. Diabetes Obes Metab (2016) 18(5):508-18. doi: 10.1111/ dom. 12644

39. Gunnarsson PT, Winzell MS, Deacon CF, Larsen MO, Jelic K, Carr RD, et al. Glucose-Induced Incretin Hormone Release and Inactivation Are Differently Modulated by Oral Fat and Protein in Mice. Endocrinology (2006) 147 (7):3173-80. doi: 10.1210/en.2005-1442

40. Mrestani-Klaus C, Fengler A, Faust J, Brandt W, Wrenger S, Reinhold D, et al. N-Terminal HIV-1 Tat Nonapeptides as Inhibitors of Dipeptidyl Peptidase IV. Conformational Characterization. Adv Exp Med Biol (2000) 477:125-9. doi: 10.1007/0-306-46826-3_13

41. Nongonierma AB, FitzGerald RJ. Susceptibility of Milk Protein-Derived Peptides to Dipeptidyl Peptidase IV (Dpp-IV) Hydrolysis. Food Chem (2014) 145:845-52. doi: 10.1016/j.foodchem.2013.08.097 
42. Nongonierma AB, Hennemann M, Paolella S, FitzGerald RJ. Generation of Wheat Gluten Hydrolysates With(Dpp-IV) Inhibitory Properties. Food Funct (2017) 8(6):2249-57. doi: 10.1039/c7fo00165g

43. Olivos DR, McGrath LE, Turner CA, Montaubin O, Mietlicki-Baase EG, Hayes MR. Intraduodenal Milk Protein Concentrate Augments the Glycemic and Food Intake Suppressive Effects of DPP-IV Inhibition. Am J Physiol Regul Integr Comp Physiol (2014) 306(3):R157-63. doi: 10.1152/ajpregu.00358.2013

44. Yoder SM, Yang Q, Kindel TL, Tso P. Differential Responses of the Incretin Hormones GIP and GLP-1 to Increasing Doses of Dietary Carbohydrate But Not Dietary Protein in Lean Rats. Am J Physiol Gastrointest Liver Physiol (2010) 299(2):G476-85. doi: 10.1152/ajpgi.00432.2009

45. Hira T, Suto R, Kishimoto Y, Kanahori S, Hara H. Resistant Maltodextrin or Fructooligosaccharides Promotes GLP-1 Production in Male Rats Fed a HighFat and High-Sucrose Diet, and Partially Reduces Energy Intake and Adiposity. Eur J Nutr (2017) 57(3):965-79. doi: 10.1007/s00394-017-1381-7
46. Hayakawa M, Hira T, Nakamura M, Iida T, Kishimoto Y, Hara H. Secretion of GLP-1 But Not GIP Is Potently Stimulated by Luminal d-Allulose (d-Psicose) in Rats. Biochem Biophys Res Commun (2018) S0006-291X(18):30143-8. doi: 10.1016/j.bbrc.2018.01.128

Conflict of Interest: The authors declare that the research was conducted in the absence of any commercial or financial relationships that could be construed as a potential conflict of interest.

Copyright () 2021 Hira, Sekishita and Hara. This is an open-access article distributed under the terms of the Creative Commons Attribution License (CC BY). The use, distribution or reproduction in other forums is permitted, provided the original author(s) and the copyright owner(s) are credited and that the original publication in this journal is cited, in accordance with accepted academic practice. No use, distribution or reproduction is permitted which does not comply with these terms. 